Joelena Leader, PhD

University of Saskatchewan, Saskatoon, Saskatchewan, Canada

Treaty 6 Territory and the Homeland of the Métis

University of Waterloo, Waterloo, Ontario, Canada

Treaty 4 - the Haldimand Tract, Traditional Territory of the Neutral, Anishnaabe and

Haudenosaunee Peoples

Abby Goodrum, PhD

Wilfrid Laurier University, Brantford, Ontario, Canada

Treaty 4 - the Haldimand Tract, Traditional Territory of the Neutral, Anishnaabe and

Haudenosaunee Peoples

\title{
Perspectives on Telehealth Projects in Northern Communities: Lessons Learned for Decolonized Participatory Design and Assessment (Paper)
}

\begin{abstract}
Northern and Indigenous communities face well documented challenges to accessing services and are impeded by significant infrastructure and technological limitations prompting the urgency to adopt innovative approaches to overcome these barriers. Telehealth - the means of accessing healthcare services and information across distance - promises to augment services to address access issues, yet notable utilization and structural constraints remain. Drawing on a recent community-based study capturing the perspectives from four Northern Saskatchewan communities on telehealth utilization, this paper draws attention to the importance of community collaborations as crucial to better decision-making and pathways forward. Specifically, this work identifies the need for decolonized participatory design (PD) and participatory technology assessment models that consider broader socio-cultural and technical factors to inform Indigenous technology design, adoption, and assessment for long-term community benefit. Further, to this is the need for community driven approaches and engagement through knowledge mobilization strategies that could better inform future community development.

\section{Motivation/Introduction}

Many northern and remote regions across Canada face a number of unique challenges including lower levels of access to services as well as significant infrastructure and technological limitations that hinder socio-economic development (Conference Board of Canada, 2010; Hall, 2017). At the same time, Northern and remote Indigenous communities are often excluded from conversations on technology design, adoption, and assessment that, without their guidance, undermines community expertise that is critical for understanding the suitability of technologies for community needs. With many technologies developed for southern contexts, this deepens the urban-rural digital divide placing remote regions at a disadvantage to take on technology projects with real ownership and to gain socio-economic benefits that can build capacity and well-being in these communities.
\end{abstract}




\section{Background/Problem Statement}

Previous research highlights complex challenges that impede innovation and technology adoption, entrepreneurship, and economic development such as geographic remoteness and isolation, sparsely populated regions, and development approaches that limit growth (Hall, 2017). Many communities face extreme social barriers from poor housing quality and overcrowding, limited access to healthcare services (Canadian Health Services Research Foundation, 2011; Laurent, 2002; Romanow, 2002) and a lack of basic services including safe drinking water and proper sanitation (Garner, Carrière, \& Sanmartin, 2010; Hall \& Coates, 2017), affordable and adequate broadband, cell phone coverage (Health Canada and the Public Health Agency of Canada, 2017)), and stable energy sources (Coates \& Landrie-Parker, 2016).

Technology projects have the potential to address some of these challenges, however, as Hall (2020) cautions, these projects could also deepen and present new challenges if they are not created with the North, for the North. What can be learned from earlier studies is that many technologies implemented in northern communities are designed for southern/urban environments that may not fit these contexts. As a result, many technology projects have not been fully or sustainably integrated for long-term use by local communities. In part, this is due to the over-reliance on piloted technology projects that, when completed or after funding expires, often leads to underutilization or stagnation when there are limited local resources and capacity to maintain technologies or address technical issues (Exner-Pirot, 2018). In many cases, this outcome creates accessibility gaps and a lack of community buy-in or trust in projects meant for community benefit. Such failures are due to more than the lack of long-term planning or vision but run much deeper, requiring true collaboration and community ownership and control of these projects.

\section{Methodology/Theoretical Approach}

This paper reports results of a community-based qualitative study that explored healthcare technology access, adoption and use in northern and remote Indigenous communities in Canada. Telehealth - the means of accessing healthcare services and information across distance - was specifically explored, encompassing both videoconferencing units of various models used by eHealth Saskatchewan and mobile remote presence robotics developed by InTouch Health. This research captures a snapshot of community perspectives and users' experiences in relation to the social and technical factors shaping telehealth use in four Northern Saskatchewan communities: Hatchet Lake Denesuline First Nation, the Northern Villages of Ille-a-la-Crosse, and Pinehouse Lake, and the Town of La Ronge as well as external stakeholders/knowledge users working directly with these communities.

The overarching research questions guiding this project are: 1) how are Indigenous communities adopting technologies for community well-being? 2) what are the strengths and challenges for technology adoption and use across northern and remote Indigenous communities? 3) what are the best approaches to understanding technology adoption in remote and northern Indigenous communities?

This work is framed primarily through a lens of Science and Technology Studies (STS), specifically the view that technologies and users interact with each other in complex acts of 
engagement that are co-constitutive/co-created and mutually shaping (Barad, 2003; Latour, 1992; Mackay, Carne, Beynon-Davies, \& Tudhope, 2000; Orlikowski, 2007; Suchman, 2007). This STS framework is expanded through engaging with conceptualizations such as Tricksters, boundary blurring and the agency of non-human actors which have groundings in constructivism that link with and have compatibilities with Indigenous worldviews, epistemologies and ways of knowing (Ballinger, 2004; Fujimura, 1992; Haraway, 1988, 2000; Pickering, 1993; Star \& Griesmer, 1989). A mutual shaping approach following the relational and performative view of socio-technical agency serves as a pathway for examining factors shaping how technologies are designed, implemented, and used, and how technologies shape practice and meanings of sociotechnical spaces. Further, understanding the context in which telehealth technologies are situated and experienced will be increasingly critical as technological systems play greater roles in service delivery.

\section{Results}

Through exploring perspectives on existing telehealth technologies, the study revealed that there was an early failure to consider the full extent of community needs during the implementation and design from ongoing training to early assessment of existing infrastructure and human resources, which became key barriers that strained long-term sustainability of telehealth across Northern Saskatchewan communities (Leader, 2020). Based on discussions with community members, telehealth was rolled out by the province as a pilot with initial roll out lacking local integrated resources to support it and largely implemented without any direct consultation or engagement from communities in the planning or design. Through these discussions it was learned that there were limited supports and key personnel for communities resulting in overstretched human and financial resources. Additionally, there were both social and technical strengths and barriers to using the systems in the day-to-day setting. It was found that users and technologies mutually shape healthcare practices and experiences; demonstrating that technologies shape patients' and local/remote providers' use of the system in enabling and constraining ways and users shape technologies through reconfigurations to suit community needs. This provides valuable insights into the importance of community engagement and identifies the strengths and barriers for utilizing telehealth within northern and Indigenous contexts.

One key finding was that the type of technology and where the technology is located matters in terms of how communities utilize the systems. The need to match technologies to community needs is critical but requires communities to be directly involved throughout the process. The roles of local technical personnel and champions in community and regional organizations that support the sustainable development of digital technologies are therefore imperative. What has been missing to date are community-driven approaches using co-designed participatory principles for technology development and assessment which have had the most promise (Peters et al., 2018). Specifically, when communities drive the conversations and processes in designing plans for implementing technology, the information and support networks that are formed often translate into catalysts for self-determination and sustainable community development (Whiteduck, Beaton, Burton, \& O’Donnell, 2012). 


\section{Discussion/Implications}

Science and Technology Studies (STS) scholars have demonstrated the intersections between science, technology, and society by highlighting how techno-scientific developments are embedded within socio-historical and technical contexts (Bijker \& Law, 1994; Bloor, 1991; Haraway, 1991; Latour, 1987; Latour \& Woolgar, 1986; Law, 1991). STS and Human-Computer Interaction (HCI) research, particularly the literature of Postcolonial HCI, HCI4D, and Indigenous HCI, has emphasized the need to capture socio-cultural and political dimensions of technologies to highlight complexities in situated cultural contexts (Abdelnour-Nocera, Clemmensen, \& Kurosu, 2013; Ali, 2014; Hardy, Wyche, \& Veinot, 2019; Irani, Vertesi, Dourish, Philip, \& Grinter, 2010; Oudshoorn \& Pinch, 2005; Wyatt, 2005). Abdelnour-Nocera et al (2013) acknowledge that "the idea of what constitutes a useful and usable system in different cultural contexts remains partially explored at the very least" (p. 201). They further argue that HCI approaches should be reframed to better understand local and Indigenous perspectives.

Individual predictors for technology adoption (e.g., usefulness of a technology to an individual), as defined by the Technology Acceptance Model (Davis, 1989), does not fully explain the range of factors that enable or constrain adoption and use in these contexts. Moreover, it can be argued that the whole notion of technology acceptance is by definition grounded on colonial ways of knowing and experiencing technologies as well as Western epistemologies. Studies of technology adoption and acceptance have long been criticized for their Western orientation toward future solutions and failure to take into account the historical and cultural realities of Indigenous peoples as well as the collective impact of their lived experiences when designing or assessing technology interventions.

Several studies point to the need for the adoption of decolonized participatory design (DPD) and participatory technology assessment models that consider broader socio-cultural and technical factors to inform Indigenous technology design, adoption and assessment for long-term community benefit (Clement \& Shade, 2000; McMahon, Gurstein, Beaton, O'Donnell, \& Whiteduck, 2014; O'Donnell et al., 2016). An argument can be made that standard participatory design practice provides a tool for decolonization in that it challenges existing power structures, has a history of engaging local and marginalized groups, and emphasizes mutual learning and cocreation. A decolonized participatory design approach expands upon PD by integrating social justice design practices that seek to provide an equitable distribution of opportunities and resources in an attempt to increase human rights and self-determination and protect the intellectual property rights of indigenous peoples (Design Justice Network, 2018; Kennedy, Kelly, Greenaway, \& Martin, 2018; Leydens, J. A., \& Lucena, J. C., \& Nieusma, D., 2014).

In this approach, design is used to sustain, heal, and empower communities, as well as to seek liberation from exploitative and oppressive systems. This includes honouring and uplifting traditional, Indigenous knowledge and practices and recognizing what is already working in the community before seeking to create something new. It means working towards sustainable, community-led, non-exploitive solutions that connect us individually and as a community. A DPD approach positions the designer as a facilitator who shares their knowledge and tools within the community. The DPD approach honours the expertise that everyone brings based on their own lived experiences and lifts up the voices of those who are directly impacted by the outcomes of the design, implementation, and assessment of solutions. In practice, a DPD approach requires 
clear strategies to engage communities and mobilize knowledge in ways that place local voices at the forefront, recognizing the important role played by community leaders and Elders in fostering community buy in and spreading the word. At the same time, how we mobilize knowledge as academics must reach beyond the academic sphere of journals and conferences, with broader reach through town halls, videos and websites and co-designing of tools that communities can continue to utilize across development projects.

We therefore call for the implementation of a novel decolonized participatory design (DPD) framework for both the design and assessment of technologies, along with community driven approaches and better engagement through knowledge mobilization strategies that could inform future community development and self-determination in northern Indigenous communities.

\section{References}

Abdelnour-Nocera, J., Clemmensen, T., \& Kurosu, M. (2013). Reframing HCI Through Local and Indigenous Perspectives. International Journal of Human-Computer Interaction, 29(4), 201-204. https://doi.org/10.1080/10447318.2013.765759

Ali, M. (2014). Towards a Decolonial Computing. In Ambiguous Technologies: Philosophical Issues, Practical Solutions, Human Nature (pp. 28-35). International Society of Ethics and Information Technology.

Ballinger, F. (2004). Living Sideways: Tricksters in American Indian Oral Traditions. Norman: University of Oklahoma Press.

Bijker, W. E., \& Law, J. (Eds.) (1994). Shaping Technology/Building Society: Studies in Sociotechnical Change. Cambridge, MA: MIT Press.

Bloor, D. (1991). Knowledge and social imagery. Chicago: University of Chicago Press.

Canadian Health Services Research Foundation (2011). Provincial and Territorial Health System Priorities: An Environmental Scan. Health (San Francisco). (December).

Clement, A., \& Shade, L. R. (2000). The access rainbow: conceptualizing universal access to the information/communications infrastructure. In M. Gurstein (Ed.), Community informatics: Enabling communities with information and communications technologies (pp. 32-51). Hershey, USA: Idea Group Publishing.

Coates, K., \& Landrie-Parker, D. (2016). Northern Indigenous Peoples \& The Prospects for Nuclear Energy. Saskatoon, SK.

Conference Board of Canada (2010). Northern communities often lack the basic attributes needed to thrive. Conference Board of Canada, 3-7.

Davis, F. D. (1989). Perceived Usefulness, Perceived Ease of Use, and User Acceptance of Information Technology. MIS Quarterly, 13(3), 319-340. Retrieved from https://www.jstor.org/stable/249008

Design Justice Network (2018). Design Justice Network Principles. Retrieved from https://designjustice.org/read-the-principles

Exner-Pirot, H. (2018). Challenges to Telehealth Implementation - Northern and Indigenous Health and Healthcare. Retrieved from https://openpress.usask.ca/northernhealthcare/chapter/chapter-25-challenges-to-telehealthimplementation/ 
Fujimura, J. (1992). Crafting science: standardized packages, boundary objects, and "translation". In A. Pickering (Ed.), Science as Practice and Culture (pp. 168-211). Chicago: University of Chicago Press.

Garner, R., Carrière, G., \& Sanmartin, C. (2010). The Health of First Nations Living OffReserve, Inuit, and Métis Adults in Canada: The Impact of Socio-economic Status on Inequalities in Health (No. Catalogue no. 82-622-X - No. 004.). Ottawa.

Hall, H. (2017). Exploring Innovation in Northern Canada with Insights from the Mining Innovation System in Greater Sudbury, Ontario. The Northern Review. (45), 33-56. https://doi.org/10.22584/nr45.2017.003

Hall, H. (2020). Innovation, new technologies, and the future of the Circumpolar North. In K. Coates \& C. Holroyd (Eds.), The Palgrave Handbook of Arctic Policy and Politics. Cham, Switzerland: Palgrave Macmillan.

Hall, H., \& Coates, K. (2017). Missed opportunities, glimmers of hope: Aboriginal communities and mineral development in Northern Ontario. Retrieved from Macdonald-Laurier Institute website: https://macdonaldlaurier.ca/files/pdf/MLIAboriginalResources12HallCoatesWeb_F.pdf

Haraway, D. (1988). Situated Knowledges: The Science Question in Feminism and the Privilege of Partial Perspective. Feminist Studies, 14(3), 575-599. https://doi.org/10.2307/3178066

Haraway, D. (1991). Simians Cyborgs and Women: The Reinvention of Nature. New York: Routledge.

Haraway, D. (2000). A cyborg Manifesto: Science, technology and socialist-feminism in the late twentieth century. In D. Bell \& B. M. Kennedy (Eds.), The Cybercultures Reader (pp. 291324). New York: Routledge.

Hardy, J., Wyche, S., \& Veinot, T. (2019). Rural HCI Research. Proceedings of the ACM on Human-Computer Interaction, 3(CSCW), 1-33. https://doi.org/10.1145/3359298

Health Canada and the Public Health Agency of Canada (2017). Evaluation of the eHealth Infostructure Program 2011-2012 to 2015-2016. Ottawa.

Irani, L., Vertesi, J., Dourish, P., Philip, K., \& Grinter, R. E. (2010). Postcolonial computing: A lens on design and development. In Chi '10: Proceedings of the SIGCHI Conference on Human Factors in Computing Systems (pp. 1311-1320). New York, NY, USA: ACM Press.

Kennedy, R., Kelly, M., Greenaway, J., \& Martin, B. (2018). International Indigenous Design Charter: Protocols in professional design practice for sharing Indigenous knowledge. Indigenous Design Charter. Geelong, Australia: Deakin University. Retrieved from https://www.ico-d.org/database/files/library/International_IDC_book_small_web.pdf

Latour, B. (1987). Science in action: how to follow scientists and engineers through society. Cambridge: Harvard University Press.

Latour, B., \& Woolgar, S. (1986). Laboratory life: the construction of scientific facts. Princeton: Princeton University Press.

Laurent, S. (2002). Rural Canada: Access to health care. Retrieved from http://publications.gc.ca/collections/Collection-R/LoPBdP/BP/prb0245-e.htm

Law, J. (Ed.) (1991). Sociology of Monsters: Essays on power, technology, and domination. London: Routledge. 
Leader, J. (2020). Mutual Shaping of Tele-Healthcare Practice: Exploring Community Perspectives on Telehealth Technologies in Northern and Indigenous Contexts (Dissertation). University of Saskatchewan, Saskatoon, SK.

Leydens, J. A., \& Lucena, J. C., \& Nieusma, D. (2014). What is Design for Social Justice? In 2014 ASEE Annual Conference \& Exposition. Retrieved from 10.18260/1-2--23301

McMahon, R., Gurstein, M., Beaton, B. [Brian], O'Donnell, S. [Susan], \& Whiteduck, T. [Tim] (2014). Making Information Technologies Work at the End of the Road. Journal of Information Policy, 4, 250. https://doi.org/10.5325/jinfopoli.4.2014.0250

O'Donnell, S. [S.], Beaton, B. [Brian], McMahon, R., Hudson, H. E., Williams, D., \& Whiteduck, T. [T.] (Eds.) (2016). Digital Technology Adoption in Remote and Northern Indigenous Communities in Canada.

Oudshoorn, N., \& Pinch, T. (Eds.) (2005). How users matter. The co-construction of users and technologies. Cambridge: MIT Press.

Peters, D., Hansen, S., McMullan, J., Ardler, T., Mooney, J., \& Calvo, R. A. (2018). "Participation is not enough". In G. Buchanan \& D. Stevenson (Eds.), Proceedings of the 30th Australian Conference on Computer-Human Interaction (pp. 97-101). New York, NY, USA: ACM. https://doi.org/10.1145/3292147.3292204

Pickering, A. (1993). The Mangle of Practice: Agency and Emergence in the Sociology of Science. American Journal of Sociology, 99(3), 559-589. https://doi.org/10.1086/230316

Romanow, R. J. (2002). Building on Values: The Future of Health Care in Canada (No. 0662330439).

Star, S. L., \& Griesmer, J. (1989). Institutional ecology: 'translations' and boundary objects: amateurs and professionals in Berkeley' Museum of Vertebrate Zoology, 1907-39. Social Studies of Science, 19, 387-420.

Whiteduck, T. [T.], Beaton, B. [B.], Burton, K., \& O’Donnell, S. (2012). Democratic Ideals Meet Reality: Developing Locally Owned and Managed Broadband Networks and ICT Services in Rural and Remote First Nations in Quebec and Canada. Keynote paper for the Community Informatics Research Network (CIRN) Conference, Prato, Italy.

Wyatt, S. (2005). Non-users also matter. The construction of users and non-users of the internet. In N. Oudshoorn \& T. Pinch (Eds.), How users matter. The co-construction of users and technologies (pp. 67-80). Cambridge: MIT Press. https://doi.org/10.1353/tech.2006.0041 